\title{
(A4) ALTERINATE
}

PLATFORM

\section{Self-directed learning as a method for future education}

Suné Bester

JUNE EDITION - 'YOUTH MONTH'

Self-directed learning can be defined as learning to learn (Zahran 2019). Self-directed learning can also be seen as an approach to pursue learning throughout life (Salleh et al. 2019). Koç (2019) defines self-directed learning as a concept that is found in individuals who are efficient in controlling their learning on their own choices and preferences. Selfdirected learning represents student-directed learning, which means that the teacher serves as the facilitator and the learners are mainly responsible for finding solutions to complete tasks and other activities (Brandt 2020). This article aims to establish the importance of self-directed learning for future education.

Self-directed learning can be seen as developmental because it helps learners to achieve their goals, solve different problems, develop a range of skills and knowledge, and realise their full potential (Brandt 2020). Zahran (2019) adds to Brandt (2020) and states that learning to learn or self-directed learning incorporates independent, self-efficient and self-regulated learning. Self-directed learning will help the learners develop the ability to evaluate the different processes and products through self-reflecting (Bishara 2021). It also encourages learners to play an active role in their learning (Demircioğlu et al. 2018). When a learner is self-directed, he/she becomes the developer of their learning objectives and goals (Zahran 2019). Furthermore, self-directed learning includes the learners in deciding what, when, and how they learn (Demircioğlu et al. 2018). Learners can also select suitable methods and strategies to achieve different learning aims (Gencel and Saracaloğlu 2018). Saeid and Eslaminejad (2017) add to Gencel and Saracaloğlu (2018) and say that the learners select, manage and assess their learning tasks and activities, which they can pursue at any time, place, through any means, and at any age. 
Although learning is the learner's main responsibility in self-directed learning, the teachers also play an active role in the learner's learning. Koç (2019) adds to Brandt (2020) and states that individuals accept the responsibility of their work with the necessary support of their mentors, teachers, or tutors. The teacher becomes a mentor for the learners and guides them through their learning process by creating a range of opportunities, and activities that are consistent with each learners' level of readiness (Bishara 2021). Teachers must scaffold and facilitate the learning process in addition to teaching the content (Brandt 2020). They should also be guides to learning rather than transmitters of knowledge (Bishara 2021).

Different factors play an important role in the development of the learners' selfdirected skills. Learner's social and environmental interactions play a critical role in the development of their self-directed learning skills; it is thus important that they engage with other learners (Brandt 2020). Self-directed learning skills are best taught through observation and practice in schools and communities (Brandt 2020). The learning environment is also an important aspect to ensure effective self-directed learning. A flexible learning environment must be provided for the learners to learn, and the learners must be prepared for this process (Gencel and Saracaloğlu 2018). Furthermore, teachers must be role models of self-directed learning by enhancing learning and motivating all learners in their learning. Lastly, feedback also plays an essential role in the development of self-directed learning as it encourages learners to develop the ability to reflect on their work and then improve on it (Brandt 2020).

Karatas and Zeybek (2020) state that $21^{\text {st }}$-century individuals and learners are expected to develop original ideas for solutions to problems that they encounter in their day-to-day life. Jaleel and Anuroofa (2017) add to Karatas and Zeybek (2020) and say that self-directed learning is an essential skill required in the $21^{\text {st }}$ century because this learning approach increases the motivation of learners to learn as they are responsible for their knowledge, and they experience a sense of independence in their learning. Learners are taught to solve problems of a specific situation and evaluate different outcomes, which are not only important in schooling but also contribute to life-long development (Kim and Lee 2018). Furthermore, Karatas and Zeybek (2020) adds that individuals in the $21^{\text {st }}$ century must try different solutions, take into consideration different perspectives, be able to analyse, criticise and question, quickly adapt to new situations, cooperate, take responsibility, and be open to criticism. The $21^{\text {st }}$-century learner has different challenges in their day-to-day life and self-directed learning will empower them to solve the challenges effectively. 
In conclusion, self-directed learning is considered an imperative educational objective throughout every person's life (Zahran 2019). In self-directed learning, it is required that learners set their strategies and goals of learning, make decisions based on different aspects of learning and life and evaluate situations and sustain their motivation (Dagal and Bayindir 2016). To ensure effective self-directed learners, rich learning environments must be developed to support the $21^{\text {st }}$-century learner (Karatas and Zeybek 2020). Furthermore, the learners' needs should also be taking into consideration for them to benefit from different experiences (Karatas and Zeybek 2020). Learners must be given ample opportunities to be taught different self-directed learning skills (Brandt 2020). Selfdirected learning is an essential skill needed in education and can enhance learners' skills throughout their lives. 


\section{References}

Bishara, S. 2021. 'The cultivation of self-directed learning in teaching mathematics'. World Journal on Educational Technology 13 (1): 82-95.

Brandt, W.C. 2020. Measuring Student Success Skills: A Review of the Literature on SelfDirected Learning. National Center for the Improvement of Educational Assessment, Dover, NH.

Dagal, A.B. and Bayindir, D. 2016. 'The Investigation of the Level of Self-Directed Learning Readiness According to the Locus of Control and Personality Traits of Preschool Teacher Candidates. International Electronic Journal of Elementary Education 8 (3): 391-402.

Demircioğlu, Z.I., Öge, B., Fuçular, E.E., Çevik, T., Nazlıgül, M.D., Özçelik, E. 2018. 'Reliability, Validity and Turkish Adaptation of Self-Directed Learning Scale (SDLS)'. International Journal of Assessment Tools in Education 5 (2): 235-247.

Gencel, I.E. and Saracaloğlu, A.S. 2018. 'The Effect of Layered Curriculum on Reflective Thinking and on Self-Directed Learning Readiness of Prospective Teachers. International Journal of Progressive Education 14 (1): 8-20.

Jaleel, S. and Anuroofa, O.M. 2017. 'A Study on the Relationship between Self Directed Learning and Achievement in Information Technology of Students at Secondary Level', Universal Journal of Educational Research 5 (10): 1849-1852.

Karatas, K. and Zeybek, G. 2020. 'The Role of the Academic Field in the Relationship between Self-Directed Learning and 21st Century Skills', Bulletin of Education and Research 42 (2): 33-52.

Kim, S. and Lee, K. 2018. 'Development and Validation of Self-directed Learning Ability Test (SDLAT) for Elementary School Students. International Electronic Journal of Elementary Education (IEEE) 10 (5): 551-557.

Koç, S.E. 2019. 'The relationship between emotional intelligence, self-directed learning readiness, and achievement'. International Online Journal of Education and Teaching (IOJET) 6 (3): 672-688.

Saeid, N. and Eslaminejad, T. 2017. 'Relationship between Student's Self-DirectedLearning Readiness and Academic Self-Efficacy and Achievement Motivation in Students' International Education Studies 10 (1): 225-232. 
Salleh, U.K.M., Zulnaidi, H., Rahim, S.S.A., Zakaria, A.R.B. and Hidayat, R. 2019. 'Roles of Self-Directed Learning and Social Networking Sites in Lifelong Learning. International Journal of Instruction 12 (4): 167-182.

Zahran, F.A. 2019. 'The Impact of Corpus on EFL Pre-Service Teachers Self-Directed Learning and Oral Proficiency'. Language Teaching Research Quarterly 13(1): 85-105. 